\title{
The effects of non-academic work experience on external interaction and research performance
}

\begin{abstract}
We ask whether academic employees with non-academic work experience differ from their colleagues with respect to interaction with external stakeholders and research performance. We use a science and technical human capital perspective and address the question through an analysis of 4,400 survey responses from academic employees in Norwegian universities and colleges. Non-academic work experience is common in all academic fields; it characterises more than half of the tenured academic staff members in Norway. Our analysis indicates that, in general, external interaction is positively influenced by non-academic work experience, in line with prior research. Contrary to expectations, we find few signs of a trade-off or a "punishment" effect of non-academic work experience on scientific productivity. Non-academic work experience is neither significantly related to publication productivity nor share of publications in highly ranked journals, but there are important differences based on the type of previous work experience.
\end{abstract}

\section{Introduction}

The purpose of this article is to explore the knowledge production and external interaction activities of academic employees with non-academic work experience. Prior research has documented that work experience from industry influences the propensity of academics to engage in universityindustry collaboration as well as in commercialisation activities (Bozeman et al., 2013; Dietz \& Bozeman, 2005; Clarysse et al., 2011; Abreu \& Grinevich, 2013). Prior studies have focused mainly on academic employees within science and engineering, and we will expand the perspective by looking at academic careers within all fields of science. There has lately been a call for research on crosssector mobility, particularly how experience from sectors outside academe influences academic work (Fernandez-Zubieta et al., 2015). We contribute here by investigating in detail the possible effects of non-academic work experience among academics. The main contribution of this paper is to compare work experiences from a range of settings, such as hospitals, schools, applied research institutes, public sector organisations, and firms, and to look at the effects of work experience on two aspects of academic work. In the science and innovation studies literature, much less is known about other types of work experience than from firms. Knowledge of academic employees and their competences is therefore limited, as it is fair to assume that many academics will have worked outside universities.

We build on the literature on "science and technology human capital" (Bozeman et al., 2001) which argues that diversity of job experiences will affect collaborative patterns and the exchange of human capital through the build-up of a wider variety of network ties (Bozeman et al., 2013). This perspective has been used to shed light on, in particular, how university-industry relations may be 
tied to individual-level human and social capital among academics engaged in different types of activities and work (Dietz \& Bozeman, 2005; Lin \& Bozeman, 2006). Some of these studies have pointed at tensions between pursuing a 'pure' academic career and having a wider set of work experiences and activities (see Bozeman et al., 2013). Shedding light on this potential dilemma is important for making good advice to policymakers and university leaders. At first sight, the implications from research, which indicates that diversity of experiences is positive for external engagement, would be to recommend recruitment of more academic personnel with non-academic work experiences. But this advice neglects individual and discipline specific characteristics and the fact that academic employees have to meet several different performance criteria.

This paper will look into the issue of non-academic competencies in relation to academic work across multiple fields of science; an issue which potentially has wide implications for recruitment and human resource management policies in universities. The paper addresses the following research questions: First, what are the main differences between academics with and without non-academic work experience in terms of participation in external engagement activities and in terms of research performance? Second, to what extent do such differences vary by fields of science and types of nonacademic work experience? To answer these questions, we analyse data from a survey with 4400 respondents from all academic disciplines and all universities and colleges in Norway. In the next section, we review the literature and formulate a set of hypotheses based on prior research and theory. After this, we turn to data and methodology and to the empirical analysis, discussion and conclusions.

\section{Literature and hypotheses}

The last 20 years have seen a strong growth in studies of university-industry relations. The first work on this issue was exploratory in nature, mapping universities' general importance to innovation (e.g. Rosenberg \& Nelson, 1994). Early empirical investigations focused mainly on research collaboration and commercialisation activities (see Rothaermel et al., 2007). Later studies have emphasised the individual level rather than institutional aspects and a wider set of interaction activities and a broader range of academic fields (Gulbrandsen et al., 2011; Perkmann et al., 2013). The general finding from studies that have looked at the heterogeneity of interaction patterns, is that there are subject-field specific patterns of interaction with external stakeholders, and that research partnerships and commercialisation activities are the least common forms (Bekkers \& Bodas-Freitas, 2008; Abreu \& Grinevich, 2013; Perkmann et al., 2013).

These shifts and expansions means that the language and perspectives we use to denote universities' engagement in society have become more complex and, maybe, more confusing. What is now seen as relevant for understanding universities' societal role is two-way interaction with a large number of stakeholders, not just firms, echoing a shift in perspectives on innovation towards non-economic forms of innovation and wider social effects of innovation and entrepreneurship. Some of the literature still favours terms like academic entrepreneurship and university-industry relations, but in wider meanings than what was common 15-20 years ago. Concepts such as academic engagement (rather than entrepreneurship) and stakeholder interaction (rather than industry interaction and/or technology transfer) are increasingly preferred. In this article we will use the terms academic engagement and external interaction, and we see industry partnerships and commercialisation 
activities as subsets of these broader activities whereby academics work to diffuse and make use of scientific knowledge and expertise outside academe.

Earlier investigations have looked at individual-level determinants of interaction with firms or engagement in commercialisation of research. However, non-academic work experience has seldom been used as an explanatory variable. Studies that take a broader perspective on academic engagement see non-academic work experience as particularly interesting, but not a lot of empirical evidence has emerged on this issue so far. Non-academic work experience denotes an indirect linkage in itself, and many studies have tied this experience to external interaction, and in particular interactions that rely on personal contacts and networks (e.g. Abreu \& Grinevich, 2013; Dietz \& Bozeman, 2005). However, we do not have broad-based evidence even on how widespread nonacademic work experience among academic employees is. 40 per cent of Lin \& Bozeman's (2006) sample of researchers from industry-oriented research centres in the US had industry work experience, but the authors note that this is most likely much higher than elsewhere in academia. Consequently, there is a need for looking beyond a few disciplines (typically engineering and natural science) and a few types of institutions (typically leading and research-intensive universities) - as well as beyond industry employment only. For example, among academic staff in life sciences and medicine, employment based links to hospitals are important for understanding academic profiles and performance (van Rijnsoever et al., 2008).

A recent large UK survey with more than 20,000 respondents looked at participation in different types of "academic entrepreneurship", ranging from licensing and spin-off activity to consultancy, contract research, informal advice and public lectures (Abreu \& Grinevich, 2013). A set of variables in the analysis concerned previous work experience, distinguishing between prior employment in small firms, large firms, the public sector and "third sector" (NGOs). Having no non-academic work experience was significantly and negatively related to all forms of academic entrepreneurship/ engagement, giving strong support to the notion that the type of networks acquired through job experience are central to external engagement. More nuanced findings were largely as expected, e.g. that public sector employment was negatively related to commercialisation and positively related to public lectures and informal advice. The finding that industrial work experience, particularly from small/newly established firms, is tied to engagement in commercialisation in a wider sense has been found in other studies as well (e.g. Lubango \& Pouris, 2007).

One explanation for these findings is that external interaction or engagement is costly in various ways. Many studies view networks as an individual resource that can be used for engaging in various activities and promoting one's career (van Rijnsoever et al., 2008). These networks can be based on ongoing or earlier collaboration, but contacts from prior work experience probably represents an important network resource for academics.

In several studies made by Bozeman and colleagues, non-academic work experience is tied to the term "scientific and technical (S\&T) human capital", which "is the sum of the scientist's technical knowledge and skills and ties to professionally relevant networks" (Lin \& Bozeman, 2006:271, italics in original). S\&T human capital encompasses skills and knowledge related to educational background (a traditional concept of human capital) as well as to the know-how, tacit knowledge and know-who that comes with work experience and personal acquaintances (more related to social capital). The assumption is that work experience leads to skills and knowledge as well as a personal network, and 
that these are resources that can be drawn upon in later circumstances. S\&T human capital is a multifaceted concept. One could talk about a "level" or "degree" of such capital, but it may be more relevant to look at how diverse it is and how it can be related to different forms of previous work experience. Diversity of S\&T human capital has been a central explanation in investigations of publication and patenting productivity among academics (Dietz \& Bozeman, 2005; Lin \& Bozeman, 2006) and external collaboration (Lubango \& Pouris, 2007; Abreu \& Grinevich, 2013).

This literature reviewed here leads us to expect that, in general, academics with non-academic work experience will have a more diverse S\&T human capital than their peers, and that this may influence their behaviour in several ways that might to different degrees be instrumental for academic success.

Although the evidence is not very substantial at this point, prior research indicates that work experience from outside academia is positive for external interaction activities among academics (Hypothesis 1). As seen above, this has been found to be the case of prior industry work experience and academics' propensity for interacting with industry. We know little about whether other forms of non-academic work experience are equally important and how they relate to interaction with other sectors of society, but following the S\&T human capital perspective and Abreu \& Grinevich (2013), we will expect that this is the case in academic fields that interact mainly with the public and third sectors as well.

At the same time, several research results point at tensions between engagement and more academic forms of success criteria. Dietz \& Bozeman (2005) argue in general that previous industrial employment provides both "opportunities" and "contamination". Van Rijnsoever et al. (2008) found that an academic career (promotion) is strongly related to an individual's scientific network, but negatively related to industry work experience. Lin \& Bozeman (2006) found that industry work experience negatively influences publications later in the academic career. The underlying reasons are not clear. It could be that the ones with non-academic work experience simply have fewer years of specialised scientific training or fewer years to publish. Lin \& Bozeman (2006) find no differences in publication rates for a cross-section of a few years between those with and without industrial work experience, but significant differences over their entire careers. This clearly warrants further investigation, but based on earlier research the assumption would be that non-academic work experience has a negative effect on academic performance (Hypothesis 2 ).

Diverse S\&T human capital can be tied to academic outputs and profiles in different ways. Intimate knowledge about practical work settings probably makes it easier for individuals to combine a formalised science and technology based innovation mode of work with a more informal practicebased mode of work, a combination that has been shown to be particularly related to high levels of innovation (Jensen et al. 2005). Another likely effect of diverse networks is more openness in various phases of the research process; different types of openness have been shown to be based strongly on individuals' past experiences (Olmos-Peñuela et al., 2015). As such diverse S\&T human capital can be related to epistemic and cognitive aspects of research, for example related to much-debated concepts such as "transdisciplinary research", "research in the context of application" and combinations of quests for fundamental understanding and societal problem-solving (Gibbons et al., 1994; Stokes, 1997; Nowotny et al., 2001). A major finding is that especially in new and crossdisciplinary research centres, academic careers are different than just a few decades ago, 
necessitating fresh perspectives on and investigations of traditional issues such as academic productivity and external networking (ibid., see also Bozeman et al., 2013).

What this research seems to indicate is that in new and interdisciplinary research areas, academic careers are changing and that in certain areas there might not be a trade-off between academic productivity and untraditional academic careers. External work experience may enable academics to select interesting research problems and secure funding for their research, which may be positively related to research performance (Bozeman et al., 2013). We therefore assume that the negative effect of non-academic work experience will vary by field of science, by sector of past employment and the duration of employment outside academe. To test this, we formulate the following hypothesis: Negative effects of non-academic work experience on research performance depend on the earlier sector of employment (Hypothesis 3).

The validity of these expectations is still an open question, which this paper seeks to find some answers to. Presently it is not clear how common non-academic work experience is among academics, how large the differences in interaction and research performance can be expected to be, and whether there are variations between types of non-academic work experiences and fields of science. Establishing a baseline from a complete set of a country's higher education institutions may therefore have some value in itself.

\section{Methods, variables and data}

To test the hypotheses, we use data from a survey of academic staff in Norway ( $N=4440)$ that contains information about a wide range of characteristics. In this paper, we draw on variables concerning prior work experience before entering the academic profession, participation in external interaction activities and information on research activities. In addition to the survey responses, we have matched the survey data with information on publication output for each individual that responded to the survey.

The survey was sent to approximately 80 per cent of the Norwegian population of academic employees, and received a response rate of 52.5 per cent. Tests were carried out to see whether the respondents differed from the whole population of academic employees in Norway in terms of age, type of position, place of work and discipline. They do not, and the data set is seen as representative of the whole population of academic staff members in the country - and it contains answers from around 40 per cent of all of them. The sample was drawn from a national registry containing address and other personal information about all tenured faculty members in Norwegian higher education institutions, meaning that $\mathrm{PhD}$ students and postdocs did not receive the survey. This is important because we want to look at the role of non-academic work experiences for performance in academic jobs, which means that individuals in tenured positions are most relevant as they have had longer careers.

All Norwegian higher education institutions were included in the sample (ranging from regional colleges to large research universities) as well as all fields of research. Compared to many other surveys, we cover fields that are normally not discussed in the literature on universities' external collaboration: large fields such as nursing, teacher training and business administration in addition to all the regular scientific disciplines. We believe this is an important contribution but it should also be kept in mind when comparing our results to those of other investigations. 


\subsection{Independent variables}

Prior work experience: In the investigations referred to in the theory section, there is no standard way of asking about work experience. For most of the survey-based papers, it is not clear how questions were asked, and for those using CV information it is not clear which kinds, stages and duration of external employment would be most relevant (Lin \& Bozeman, 2006). Lin \& Bozeman used a dummy variable (yes/no) and then collected information about the numbers, timing and length of industry employment from academic CVs. Since we could not collect as detailed information using a comprehensive survey that covered multiple issues, we chose instead to ask respondents about whether they had at least one year of full-time employment outside of academia after finishing their master's degree. We wished to avoid work experience to be related to part-time employment during education, for example. Our assumption was that a year of full-time employment after a master's degree would have lasted long enough to have an impact on their S\&T human capital. A fairly lengthy job period might also have an influence on the mind-set and perspectives of the individuals.

The respondents that confirmed that they had at least one year of non-academic work, received a follow-up question asking them to list the sector of employment where they had mainly worked before taking up a tenured academic position (applied research institutes, healthcare, schools, other public organisations, private firms/industry). We thought it would be interesting to include large sectors such as healthcare and schools in addition to industry and the public sector to capture variety in non-academic work experience. In Norway, like in other countries such as Germany, Spain and the Netherlands there is a large research performing sector, besides firms and higher education institutions, where a little less than one-third of the research activities in the country are performed. There is a significant turnover from these research organisations to higher education institutions, and we wanted to see whether these individuals differed from their colleagues without this background.

We have furthermore added several control variables based on what is already known about external interaction and research performance. First, we include gender since a consistent finding in the literature is that women are less likely to engage in some forms of interaction (particularly commercialisation activities) than men (see Perkmann et al. 2013; Gulbrandsen et al. 2011). Second, we control for the research field, which as outlined above is a major influence on external interaction. Third, we include type of academic position because earlier investigations have found a clear seniority effect in external interaction - this is much more common among full professors. Our data allows us to distinguish between full, associate and assistant professors as well as academics in various leadership positions (department heads, deans, centre leaders etc.). Fourth, we add one variable concerning external funding. Earlier investigations have found a clear relationship between external funding and both external interaction and research performance (e.g. Gulbrandsen \& Smeby, 2005; Larsen 2011). Finally, we control for the degree to which the respondents define their research activities as oriented towards basic research and applied research; earlier investigations have found that interaction is particularly common among those who predominantly define their profile as applied (Gulbrandsen \& Smeby 2005). The correlation between these variables is low. For example, although the ones with non-academic work experience have a more applied research profile, the correlation between these variables is only .14, and the correlation between basic and applied research is -.08 . Other correlation coefficients are in this range which reduces problems of multicollinearity. 


\subsection{Dependent variables}

External interaction: To measure participation in external interaction, we draw a question with many sub-items. We asked about whether the respondents during the last three years had participated in different types of external interaction, ranging from patenting to invited lectures (we use 18 items in total in our analysis). The categories were based on the survey reported in Abreu \& Grinevich (2013) with a few minor adaptations to the Norwegian context. A factor analysis was applied using principal component analysis, Equimax with Kaiser Normalisation to balance concerns about level of factor loadings with unambiguous loadings on each factor (Brown 2009). This gave us four main categories: dissemination (popular science publishing, contribution to public debate, invited lectures for users/general public, participation at conferences with users/general public, consultancy/advice as expert), research collaboration (contract research with externally defined theme, collaborative $R \& D$ with public sector, collaborative R\&D with industry, establishment of new infrastructure/labs etc. with stakeholders), commercialisation (development/testing of prototypes, applied for patent, started new firm, licensed research results) and training (further education at university/college, training of people at their workplace, own 'sabbatical' in external non-research organisations, placement of students in working life). Details about the factor analysis are found in Table 1.

$<<$ Table 1 around here $>>$

Research performance: As Lin \& Bozeman (2006) acknowledges there is no standardised way to measure research performance. Number of scientific publications and the impact of those in terms of citation counts are standardised ways of measuring productivity and quality of publications. Lin \& Bozeman (2006) measure scientific productivity by counting the numbers of publications appearing on individuals' CVs. It would also be possible to match survey data with bibliographic data in publication databases. We rely on the second option, and use data from a national bibliographic database. In Norway, a portion of public research funding is distributed based on publication scores. Each academic employee has to register all publications in a national database called CRISTiN, which contains a list of all approved journals and publishing houses that publishes academic books (they are checked for having serious peer review).

Approved scientific outlets are furthermore classified as Level 1 and Level 2 outlets. Level 2 outlets are the most significant and prestigious journals/publishers in each scientific field as decided by national disciplinary peer committees. No more than 20 per cent of the journals/publishing houses in each scientific field can be classified as Level 2 . An article in a leading journal yields 3 publication points, while an article in a Level 1 journal yields 1 ; for book chapters the corresponding scores are 1 and 0.7 and a whole (non-edited) book yields 8 or 5 points. Publication points are adjusted for coauthorships, for example if there are three authors, each gets $1 / 3$ of the points. A central value of using this database is that it covers both journals and other kinds of scientific publications (book chapters and books), which is necessary when studying research performance in multiple academic disciplines, especially fields such as social science and humanities. Using bibliographic information such as citation counts or impact factors would mean that we would not have information relevant for a substantial part of the sample. We opted to use to publication scores contained in CRIStin, and matched parts of the CRIStin database with our survey data set so that we have information about total publication points for each individual (adjusted for co-authorship) for a period of three years (2011, 2012 and 2013), as well as the share of their publications at the most prestigious "Level 2". Information about the publications (journal, citations etc.) is not available. 
We use this to construct two dichotomous variables related to productivity and quality. High productivity is defined as having more than 3 publication points in the period in question. As this applies to slightly less than 20 per cent of the respondents (the average number of points is 1.64), this is an adequate indicator to discern high performers. High quality is defined as having more than half of the publications in the leading "Level 2" journals and publishing houses, and more than one publication in total. This is done to avoid placing respondents with only one Level 2 publication in the high quality group. Our definition of "high quality publishing" also applies to around 20 per cent of the respondents. We have tested alternatives, including regular linear regression for the total count of publication points, but the same variables emerge as significant (see below).

More details about the variables used are found in Table 2 . In the regressions concerning external interaction, we control for the total number of publication points and the share of publications in the leading journals (Level 2). Correspondingly, in the regressions about research quality and productivity we control for the four types of external interaction.

$<$ Table 2 around here $>>$

\section{$4 \quad$ Results}

A surprisingly high number of the respondents in our survey, who all have permanent scientific positions in Norwegian universities and colleges, have full time work experience lasting one year or more after finishing their master's degree. 2281 individuals report this, representing 52.8 per cent, which is higher even than some of the investigations looking at external work experience for industry-oriented university research centres (Dietz \& Bozeman 2005). We show their distribution within each field of science and for each type of work experience in Table 3. Differences between fields of science are highly statistically significant and largely as expected, for example that respondents from medicine and health have worked in the health and care sector. Non-academic work experience is common in all fields and the lowest share is 45 per cent among natural science respondents. The most common form of non-academic work experience is from industry, followed by the school sector (not universities/colleges). Industry experience is, as expected, most common in technology, but there is a fair share of respondents with such experience in other fields as well (lowest score in medicine and health). There are no differences between types of higher education institutions with respect to non-academic work experience, i.e. this is as common in the large research universities as in the more regionally oriented and applied university colleges.

$<<$ Table 3 around here $>>$

Without controlling for anything, we have also explored some differences between individuals with and without non-academic work experience when it comes to research profiles, shown in Table 4. It can be noted that even if the differences are statistically significant, they are also quite small when it comes to research profiles. Individuals with non-academic work experience to a somewhat higher extent define their research as applied, and they see their research as focusing on fundamental understanding and scientific originality to a somewhat lesser extent. As expected, the ones with nonacademic work experience generally score higher on external funding of research, although the absolute differences are small here as well. The differences are particularly large related to funding from public organisations and from firms, which may be situations where social capital plays a higher role than when applying for research council funding or EU funding. There are no significant 
differences between the two groups when it comes to international funding as well as for funding from non-profit sources such as private foundations. Finally, academics with non-academic work experience have somewhat fewer publication points and a somewhat lower share of publications in leading international journals, compared to peers with no non-academic work experience.

$<$ Table 4 around here $>>$

Turning to external interaction and a more sophisticated analysis, we find that non-academic work experience is significantly and positively related to dissemination, research collaboration and training, but not to commercialisation. The binary logistic regressions are shown in Table 5. There are clear differences between fields, and they are largely as expected (for example humanities and social science more involved in dissemination, natural science and technology more in commercialisation). Having an applied research orientation is positively related to all forms of external interaction, and having no external research funding negatively related to all forms. This is in line with earlier research and corresponds well to the S\&T human capital perspective. Non-academic work experience is associated with a more diverse S\&T human capital, which in various ways provides opportunities for external engagement.

$<<$ Table 5 around here $\gg>$

The results from the comparison between academics with and without non-academic work experience are in line with prior knowledge; non-academic work experience is generally positive for external interaction. We do not, however, see strong indications of a normative preference for applied work among academics with non-academic work experience.

Our next step was to run the external interaction regressions including dummy variables for different types of non-academic work experience instead of the binary variable for such experience. Interesting new patterns emerge here. The results of these regressions (shown in Table 6) are that for dissemination and training activities, academics with a background from schools or health care are significantly more active that academics with other backgrounds or no non-academic work experience. Academics with a background from applied research institutes are significantly more active in research collaboration, whereas academics with background from industry or hospitals are more active than their peers in research commercialisation activities. A background from the public sector is positively related to dissemination and training, and negatively related to commercialisation, confirming earlier research.

Looking more closely at the underlying data, we see that the respondents with experience from applied research institutes have a much higher score on almost all types of research funding, which is natural since these institutes are dependent upon external funding to a much greater extent than universities and colleges. It is still interesting that this funding-seeking behaviour seems to continue even when the individual has moved to a tenured position in academia. This provides further support to the S\&T human capital perspective; this is something that seems to endure.

Turning to the research productivity and quality (Table 7), the main influences here are related to seniority (being a full professor) and to an orientation towards basic research. Having external funding is also strongly related to productivity and quality (the causality is not clear, however, external funding may both be a "reward" for high research performance and a precondition for it). 
Previous non-academic work experience in general is neither related to productivity and quality the way we have operationalised them. Looking at different types of experience, the ones who have previously worked in industry have a significantly lower score on productivity, while no such effects are found for other types of experience. Having worked in a research institute is positively related to quality before we adjust for external interaction but not after, while no such effect is seen for other types of non-academic work. The regressions also show that both productivity and quality are positively related to research collaboration, which may highlight the cumulative and interactive nature of research in general.

The ambition of the article has been to investigate the external interaction activities and research performance of tenured university employees that have non-academic work experience, compared to their peers with "pure" academic careers. When comparing the ones having non-academic work experience with academics without such experience, our data largely confirms prior research results about external interaction. Non-academic work experience is significantly and positively related to involvement in dissemination, training and research collaboration (see Table 5.) Our analysis therefore provides evidence in favour of Hypothesis 1 . The exception is commercialisation where we find a positive but non-significant relationship. This might be a result of the inclusion of large fields such as nursing, business administration, law and teacher training in the material.

When it comes to research performance, we find no relationship between our two indicators of productivity and quality and having non-academic work experience (Table 7, first two columns). This leads us to reject Hypothesis 2. In general, there does not seem to be a trade-off (or a synergy) between non-academic work experience and performance. Basic research orientation, seniority and funding are the central variables related to performance.

In the more nuanced analysis of different types of previous work experience (Table 6 and last two columns in Table 7), we have found interesting differences in external interaction patterns and research performance which supports Hypothesis 3. There are major and largely expected variations between the types of work experience. For example, a public sector background is positively related to dissemination and training and negatively related to commercialisation; work experience from industry is positively related to research collaboration and commercialisation and negatively related to research productivity. This probably indicates that the most important mechanisms of interaction between higher education institutions and the rest of society differ significantly between sectors. It may also reflect differences between the academic fields, as sectors of employment for researchers in different fields vary considerably (see Table 3). An implication of these findings is that the general perspective on inter-sector mobility as valuable for external knowledge interaction is confirmed, but that only certain kinds of prior work experience are important for knowledge transfer between universities and industry. Our findings indicate a similar relationship between past employment in public sector, education and health organisations (common among academics in health and medicine, social science and humanities) and academics' propensity to engage in training and dissemination activities.

Our data indicates that there are enduring networks between sectors of employment and fields of science; academics in all fields of science continue to draw upon networks and resources related to the sector of their earlier employment. External work experience leads to more diverse S\&T human capital, but there are limits to this diversity. This is not unexpected, and our data also reveal that 
prior work experience from public sector organisations and industry is strongly related to receiving funding from these sources.

Work experience from applied research institutes is associated both with external interaction and to some degree with research quality. It seems this group to a greater extent experiences a synergy rather than trade-off between investment in broader competencies and an academic career. For those with industrial work experience, there seems to be a trade-off in terms of research productivity. These findings contribute to a better understanding of the mixed evidence for a career tension perspective that has emerged in prior research (Bozeman et al. 2013), by indicating that the trade-off is clearly present in some fields of science where career paths inside and outside the academe are much more different than in other employment sectors and fields of science. Again these results provide some support for Hypothesis 3. The positive relationship between quality and external interaction is in our case specific to individuals with prior work experience from applied research institutes. There is probably a selection effect at play here, where the most academically interested applied researchers are in various ways encouraged to apply for a university or college career.

\section{$5 \quad$ Discussion and conclusions}

The aim of this paper has been to contribute to new knowledge about the academic population, the diversity of competencies possessed by academic staff and how prior work experience influences academic performance. Earlier research has found that academics who prior to taking up employment in universities have advantages when it comes to external interaction (Abreu \& Grinevich, 2013) but disadvantages when it comes to research performance (Lin \& Bozeman, 2006 ; Van Rijnsoever et al. 2008). However, research on this topic is based on empirical data from just a few fields of science, has targeted prior industry employment only, or the results have been unclear. There have been few empirical studies of diverse career trajectories outside natural sciences and technical/engineering fields, and in general, how experience from other sectors is used in academia (Fernandez-Zubieta et al., 2015). This article has sought to make a contribution by investigating academics within all fields of research with multiple kinds of prior work experience. Apart from the gap in the scientific literature, findings might have wide implications for recruitment and human resource management (HRM) policies in universities.

Our results support and challenge existing knowledge. It should first be noted that non-academic work experience is common; 53 percent of our 4,400 respondents report this and the share is high within all fields of research although the sector of earlier work experience differs between fields. Compared to earlier investigations based primarily on previous industry employment these figures seem high, and they indicate the great diversity of scientific and technical human capital in academia. Second, the results support the hypotheses derived from prior research concerning the positive effect of non-academic work experience on external interaction. Dissemination, external research collaboration, commercialisation and training activities (not part of regular teaching and supervision) are all positively related to non-academic work experience. Third, unlike earlier investigations we do not find strong indications of a punishment effect on research performance. Although non-academic work experience is related to a more applied research profile which is negatively related to publication productivity and quality in our data, such experience does not in itself have a significant relationship with performance. Finally, we find that the past sector of employment matters 
particularly for external engagement and to some extent for research performance. Industry experience is significantly and positively related to all forms of external interaction except training, but negatively related to research productivity. With the exception of experience from applied research institutes, all forms of non-academic work experience are negatively related to academic productivity, but only industry experience significantly so.

In total our data do not support the notion of a trade-off between non-academic work experience and academic results, but they do not indicate synergies either. The S\&T human capital gained by non-academic work experience does have a profound influence on the profiles of academics: they describe their work as slightly more applied and have a much stronger orientation towards interaction with actors outside of academia, as can be expected. Our data indicate that the effects of this are nuanced. On the one hand, non-academic experience is associated with higher levels of external research collaboration which is positively associated with publication productivity and quality. On the other hand, such experience is also associated with more involvement in training and commercialisation, and these are negatively related to productivity. The reasons are unclear and warrant further research; some of these activities may have particularly little in common with academic publication, or they may simply be very time-consuming.

Our study has some shortcomings which should be taken into account. It is based on self-reported data on careers and the definition of non-academic work experience is a fairly broad one: postgraduate work experience of at least one year. This is a less strict definition compared for instance to the one used by Bozeman \& Lin, 2006). This can probably explain why more than half of the respondents have non-academic work experience. Research drawing upon CV data might offer a better way to measure the extent and depth of work experiences and could also better measure the importance of non-academic work experience at different stages of a career path (Canibano \& Bozeman, 2009; Geuna et al., 2015). Likewise, we use self-reported data on experiences with interaction with external stakeholders, and have not asked for details about duration or intensity of interactions and partnerships. However, we have used register-based data on research productivity and quality that are more unobtrusive than self-reported data. An interesting approach in later research may be to use a matched pairs approach where individuals with similar backgrounds (gender, field of science, age etc.) yet different career patterns are compared to one another using broader and possibly longitudinal data.

Several issues for policy makers and managers may be discussed. Hiring researchers with nonacademic work experience is clearly valuable for increasing external collaboration but may not always beneficial for academic goals, especially with respect to experience from industry. This mixed message represents a policy and management challenge for universities that use recruitment and personnel management to support institutional goals. Universities are looking to recruit the most talented researchers with a potential for high scientific productivity and quality. At the same time they want academics that are motivated to communicate research results and to make an impact. One solution could be to recruit academic staff members with non-academic job experience who at the same time express a clear interest in basic research. This study indicates that public laboratories and other applied research institutes could potentially be a training ground for these kinds of researchers, at least in the Norwegian context. Another strategy would be to recruit promising scientists and integrate them in larger and more diverse groups with seniors of different backgrounds. As seen above, there is a strong seniority dimension involved; full professors take a 
greater role in external engagement activities and also score higher on quality and productivity even in a short time span. Finally, less emphasis has been placed on the training dimension of external interaction compared to commercialisation, dissemination and research collaboration. In our data training is very common and positively related to non-academic work experience. More nuanced forms of performance and promotion criteria may be needed to accommodate this dimension.

\section{References}

Abreu, M. \& Grinevich, V. (2013). The nature of academic entrepreneurship in the UK: widening the focus on entrepreneurial activities. Research Policy 42(2), 408-422.

Bekkers, R. \& Freitas, I. M. (2008). Analyzing knowledge transfer channels between universities and industry: To what degree do sectors also matter? Research Policy, 37(10):1837-1853.

Boardman, P.C. \& Ponomariov, B.L. (2009). University researchers working with private companies. Technovation 29:142-153.

Bozeman, B., Fay, D. \& Slade, C.P. (2013). Research collaboration in universities and academic entrepreneurship: the state-of-the-art. Journal of Technology Transfer 38:1-67.

Bozeman, B., Dietz, J.S. \& Gaughan, M. (2001). Scientific and technical human capital: an alternative approach to R\&D evaluation. International Journal of Technology Management 22(8): 716.740.

Clarysse, B., Tartari, V. \& Salter, A. (2011). The impact of entrepreneurial capacity, experience and organizational support on academic entrepreneurship. Research Policy 40:1084-1093

Dietz, J.S. \& Bozeman, B. (2005). Academic careers, patents, and productivity: industry experience as scientific and technical human capital. Research Policy 34:349-367.

D'Este, P. \& Fontana, R. (2007). What drives the emergence of entrepreneurial academics? A study on collaborative research partnerships in the UK. Research Evaluation 16(4):257-270.

D'Este, P. \& Perkmann, M. (2011). Why do academics engage with industry? The entrepreneurial university and individual motivations. Journal of Technology Transfer 36:316-339.

Fernandez-Zubieta, A., Geuna, A. \& Lawson, C. 2015. What do we know of the mobility of research scientists and of its impact on scientific production. LEI \& BRICK working paper series 08/2015

Geuna, A., Kataishi, R., Toselli, M., Guzmán, E., Lawson, C., Fernandez-Zubieta, A., \& Barros, B. (2015). SiSOB data extraction and codification: A tool to analyze scientific careers. Research Policy.

Gibbons, M. et al. (2004). The new production of knowledge. The dynamics of science and research in contemporary societies. London: Sage Publications.

Gulbrandsen, M., Mowery, D. \& Feldman, M. (2011). Heterogeneity and university-industry relations: introduction to the special section, Research Policy, 40:1-5.

Lin, M.-W. \& Bozeman, B. (2006). Researchers' industry experience and productivity in universityindustry research centres: a "scientific and technical human capital" explanation. Journal of Technology Transfer 31:269-290. 
Lubango, L.M. \& Pouris, A. (2007). Industry work experience and inventive capacity of South African academic researchers. Technovation, 27:788-796.

Olmos-Peñuela, J., Benneworth, P. \& Castro-Martínez, E. (2015). What stimulates researchers to make their research usable? Towards an 'openness' approach. Minerva, online first October 2015.

Perkmann, M. et al. (2013). Academic engagement and commercialisation: a review of the literature on university-industry relations. Research Policy 42:423-442.

Roach, M. \& Sauermann, H. (2010). A taste for science? PhD scientists' academic orientation and selfselection into research careers in industry. Research Policy 39:422-434.

Stokes, D. E. (1997). Pasteur's Quadrant. Basic Science and Technological Innovation. Washington, D.C.: The Brookings Institution Press.

Tartari, V., Perkmann, M. \& Salter, A. (2014). In good company: the influence of peers on industry engagement by academic scientists. Research Policy 43:1189-1203.

Van Rijnsoever, F.J., Hessels, L.K. \& Vandeberg, R.L.J. (2008). A resource-based view on the interactions of university researchers. Research Policy 37:1255-1266. 
Table 1. Factor analysis. Asked about involvement in specific activities during last three years.

\begin{tabular}{|c|c|c|c|c|}
\hline Item & Dissemination & $\begin{array}{c}\text { Research } \\
\text { collaboration }\end{array}$ & Commercialisation & Training \\
\hline Published popular science article & 0.708 & 0.076 & 0.022 & -0.074 \\
\hline $\begin{array}{l}\text { Published contribution to public } \\
\text { debate/in the media }\end{array}$ & 0.674 & 0.032 & -0.019 & -0.067 \\
\hline $\begin{array}{l}\text { Member of board in external non- } \\
\text { academic organisation }\end{array}$ & 0.351 & 0.146 & 0.276 & 0.055 \\
\hline $\begin{array}{l}\text { Invited presentations for users/the } \\
\text { general public/practitioners }\end{array}$ & 0.678 & 0.131 & 0.052 & 0.222 \\
\hline $\begin{array}{l}\text { Participation at conferences with } \\
\text { users/practitioners/general public }\end{array}$ & 0.543 & 0.174 & 0.009 & 0.287 \\
\hline Consultancy/advisory activities & 0.416 & 0.263 & 0.202 & 0.164 \\
\hline $\begin{array}{l}\text { Contract research on externally } \\
\text { defined topic }\end{array}$ & 0.223 & 0.660 & -0.036 & -0.048 \\
\hline Research project with public sector & 0.262 & 0.548 & -0.178 & 0.120 \\
\hline $\begin{array}{l}\text { Research project with private } \\
\text { sector }\end{array}$ & 0.027 & 0.665 & 0.300 & -0.046 \\
\hline $\begin{array}{l}\text { Establ of infrastructure (labs. } \\
\text { training facilities) with ext actors }\end{array}$ & -0.042 & 0.447 & 0.279 & 0.148 \\
\hline $\begin{array}{l}\text { Development/testing of new } \\
\text { prototypes/products }\end{array}$ & -0.049 & 0.378 & 0.446 & 0.146 \\
\hline Applied for a patent & -0.002 & 0.136 & 0.693 & -0.088 \\
\hline Started a new firm & 0.057 & -0.053 & 0.626 & 0.122 \\
\hline Licensed my research results & 0.074 & 0.049 & 0.578 & -0.040 \\
\hline $\begin{array}{l}\text { Involvement in further education } \\
\text { at my institution }\end{array}$ & 0.320 & -0.081 & -0.044 & 0.579 \\
\hline $\begin{array}{l}\text { Training of workers outside of my } \\
\text { institution }\end{array}$ & 0.440 & 0.036 & -0.031 & 0.595 \\
\hline $\begin{array}{l}\text { Own practice/sabbatical in non- } \\
\text { academic organisation }\end{array}$ & -0.065 & -0.011 & 0.108 & 0.512 \\
\hline Placement of students in work life & -0.123 & 0.238 & -0.025 & 0.656 \\
\hline
\end{tabular}

Extraction method: Principal Component Analysis. Rotation method: Equamax with Kaiser normalisation. 
Table 2. Descriptives for variables used in the analyses.

\begin{tabular}{|c|c|c|c|}
\hline Variable & Description & Labels & Descriptive data (N) \\
\hline \multicolumn{4}{|l|}{ Dependent variables } \\
\hline External interaction & $\begin{array}{l}\text { Dissemination } \\
\text { Training } \\
\text { Research collaboration } \\
\text { Commercialization }\end{array}$ & $\begin{array}{l}1=\text { yes } \\
0=\text { no } \\
1=y e s \\
0=\text { No } \\
1=y e s \\
0=\text { No } \\
1=\text { yes } \\
0=\text { No }\end{array}$ & $\begin{array}{l}81.1 \%(3600) \\
18.9 \%(840) \\
64.6 \%(2869) \\
35.4 \%(1571) \\
34.5 \%(1533) \\
65.5 \%(2907) \\
13.4 \%(593) \\
86.6 \%(3847)\end{array}$ \\
\hline $\begin{array}{l}\text { High research } \\
\text { productivity }\end{array}$ & $\begin{array}{l}\text { More than three publication } \\
\text { points } 2011-2013\end{array}$ & $\begin{array}{l}1=\text { yes } \\
0=\text { no }\end{array}$ & $\begin{array}{l}18.7 \%(830) \\
81.3 \%(3608)\end{array}$ \\
\hline High research quality & $\begin{array}{l}\text { More than } 50 \% \text { of publications } \\
\text { in elite journals and more than } \\
\text { one solo-authored publication }\end{array}$ & $\begin{array}{l}1=\text { yes } \\
0=\text { no }\end{array}$ & $\begin{array}{l}8.2 \%(365) \\
91.7 \%(4073)\end{array}$ \\
\hline \multicolumn{4}{|l|}{ Independent variables } \\
\hline $\begin{array}{l}\text { Non-academic work } \\
\text { experience }\end{array}$ & $\begin{array}{l}\text { One year full time or more } \\
\text { Experience from public sector } \\
\text { Exp. from research institutes } \\
\text { Exp. from health sector } \\
\text { Exp. from school system } \\
\text { Exp. from industry }\end{array}$ & $\begin{array}{l}1=y e s \\
0=\text { no } \\
1=y e s \\
0=\text { no } \\
1=y e s \\
0=\text { no } \\
1=\text { yes } \\
0=\text { no } \\
1=\text { yes } \\
0=\text { no } \\
1=y e s \\
0=\text { no }\end{array}$ & $\begin{array}{l}53.6 \%(2281) \\
44.4 \%(1973) \\
14.0 \%(621) \\
86.0 \%(3819) \\
10.4 \%(462) \\
89.6 \%(3978) \\
9.1 \%(404) \\
90.9 \%(4036) \\
15.4 \%(683) \\
84.6 \%(3757) \\
16.0 \%(711) \\
84.0 \%(3729)\end{array}$ \\
\hline \multicolumn{4}{|l|}{ Control variables } \\
\hline $\begin{array}{l}\text { Respondents' } \\
\text { discipline }\end{array}$ & $\begin{array}{l}\text { Based on data about which } \\
\text { department/academic unit the } \\
\text { respondent works in }\end{array}$ & $\begin{array}{l}0=\text { humanities } \\
1=\text { social science } \\
2=\text { natural science/math. } \\
3=\text { technology/agriculture } \\
\text { 4=medicine/health }\end{array}$ & $\begin{array}{l}16.3 \%(725) \\
35.9 \%(1594) \\
12.0 \%(531) \\
15.4 \%(684) \\
20.4 \%(906)\end{array}$ \\
\hline Gender & Self-reported & $\begin{array}{l}0=\text { male } \\
1=\text { female }\end{array}$ & $\begin{array}{l}59.2 \%(2629) \\
40.8 \%(1811)\end{array}$ \\
\hline Academic position & Self-reported & $\begin{array}{l}\text { 1=full professor } \\
2=\text { =associate professor } \\
3=\text { lecturer/assistant professor } \\
\text { 4=academic leader }\end{array}$ & $\begin{array}{l}29.1 \%(1294) \\
36.6 \%(1623) \\
30.8 \%(1366) \\
3.5 \%(157)\end{array}$ \\
\hline $\begin{array}{l}\text { External research } \\
\text { funding. national }\end{array}$ & $\begin{array}{l}\text { National sources (research } \\
\text { council. foundations etc.) }\end{array}$ & $\begin{array}{l}1=\text { yes } \\
0=\text { no }\end{array}$ & $\begin{array}{l}57.0 \%(2530) \\
43.0 \%(1910)\end{array}$ \\
\hline $\begin{array}{l}\text { Basic research } \\
\text { orientation }\end{array}$ & $\begin{array}{l}\text { Degree of score (3-point scale) } \\
\text { on two items }\end{array}$ & Minimum 2. maximum 6 & $\begin{array}{l}\text { Mean } 4.60 \\
\text { StD } 1.24\end{array}$ \\
\hline $\begin{array}{l}\text { Applied research } \\
\text { orientation }\end{array}$ & $\begin{array}{l}\text { Degree of score (3-point scale) } \\
\text { on two items }\end{array}$ & Minimum 2. maximum 6 & $\begin{array}{l}\text { Mean } 3.94 \\
\text { StD } 1.25\end{array}$ \\
\hline
\end{tabular}


Table 3. Non-academic work experience among permanent scientific staff members in Norwegian universities and colleges.

\begin{tabular}{|c|c|c|c|c|c|c|}
\hline \multirow[b]{2}{*}{ Field } & \multicolumn{5}{|c|}{ Work experience from: } & \multirow[b]{2}{*}{$\begin{array}{l}\text { Total non } \\
\text { academic } \\
\text { work exp. }\end{array}$} \\
\hline & $\begin{array}{l}\text { Public } \\
\text { sector }\end{array}$ & $\begin{array}{l}\text { Applied } \\
\text { research } \\
\text { institutes }\end{array}$ & $\begin{array}{l}\text { Health } \\
\text { and care } \\
\text { sector }\end{array}$ & Education & Industry & \\
\hline Humanities $(\mathrm{N}=725)$ & $14.8 \%$ & $4.8 \%$ & $1.4 \%$ & $20.8 \%$ & $11.6 \%$ & $48.1 \%$ \\
\hline Social science $(\mathrm{N}=1594)$ & $20.5 \%$ & $10.0 \%$ & $5.9 \%$ & $22.4 \%$ & $14.2 \%$ & $58.6 \%$ \\
\hline Natural science/math. ( $\mathrm{N}=531)$ & $8.9 \%$ & $16.0 \%$ & $1.7 \%$ & $10.7 \%$ & $17.7 \%$ & $45.0 \%$ \\
\hline Technology/engineering $(\mathrm{N}=658)$ & $9.8 \%$ & $19.6 \%$ & $2.5 \%$ & $6.7 \%$ & $38.2 \%$ & $61.6 \%$ \\
\hline Medicine and health $(\mathrm{N}=906)$ & $8.2 \%$ & $5.3 \%$ & $30.2 \%$ & $7.9 \%$ & $5.1 \%$ & $48.3 \%$ \\
\hline Total for each type of exp. $(\mathrm{N}=4400)$ & $14.0 \%$ & $10.4 \%$ & $9.1 \%$ & $15.4 \%$ & $16.0 \%$ & $52.8 \%$ \\
\hline $\begin{array}{l}X^{2}(4) \text { significance levels ( } X^{2} \text { values } \\
\text { ranging from } 65 \text { to } 633 \text { ) }\end{array}$ & $<.001$ & $<.001$ & $<.001$ & $<.001$ & $<.001$ & $<.001$ \\
\hline
\end{tabular}

Note that the sum in the last row does not add to $52.8 \%$ because some individuals have several types of non-academic work experience. Social science includes business administration and law. 
Table 4. Research profiles for respondents with and without non-academic work experience.

\begin{tabular}{|l|r|r|r|}
\hline Question/topic from the survey & Non-academic work exp & \multicolumn{1}{l|}{ Sig. } \\
\cline { 2 - 4 } & \multicolumn{1}{|l|}{ Yes } & \multicolumn{1}{|l|}{ No } \\
\hline My research is oriented at scientific originality (3=to a high degree. 1= not at all) & 2.14 & 2.24 & $<.001$ \\
\hline My research is oriented at fundamental understanding & 2.38 & 2.47 & $<.001$ \\
\hline My research is oriented at practical problems & 2.39 & 2.20 & $<.001$ \\
\hline My research is oriented at externally defined questions & 1.71 & 1.56 & $<.001$ \\
\hline Combination of basic and applied research (Pasteur's quadrant; share of respondents) & $25.9 \%$ & $22.0 \%$ & $<.005$ \\
\hline Received research funding from Research Council of Norway (share) & $35.9 \%$ & $33.9 \%$ & $<.005$ \\
\hline Received research funding from public agencies/ministries & $22.6 \%$ & $16.6 \%$ & $<.001$ \\
\hline Received research funding from industry/private firms & $12.9 \%$ & $9.0 \%$ & $<.001$ \\
\hline Number of personal publication points over three years & 1.57 & 1.75 & $<.05$ \\
\hline Share of publications in leading international journals & $13.4 \%$ & $15.6 \%$ & $<.01$ \\
\hline
\end{tabular}


Table 5. Regressions on external engagement, external work experience in general.

\begin{tabular}{|c|c|c|c|c|}
\hline Variable & $\begin{array}{l}\text { Dissemi- } \\
\text { nation }\end{array}$ & $\begin{array}{l}\text { Research } \\
\text { collab. }\end{array}$ & $\begin{array}{l}\text { Commerciali } \\
\text { sation }\end{array}$ & Training \\
\hline Gender (male $=1$. fem $=2$ ) & .009 & -.112 & $-.790 * * *$ & .142 \\
\hline \multicolumn{5}{|l|}{$\begin{array}{l}\text { Field of science } \\
\text { (humanities=ref) }\end{array}$} \\
\hline Social science & .237 & $.793 * * *$ & .083 & $.334^{* *}$ \\
\hline $\begin{array}{l}\text { Mathematics/natural } \\
\text { science }\end{array}$ & $-.977 * * *$ & $1.108 * * *$ & $.752 * * *$ & -.090 \\
\hline Engineering/agriculture & $-.845 * * *$ & $1.557^{* * *}$ & $1.435^{* * *}$ & $-.472 * * *$ \\
\hline Medicine/health & -.228 & $1.005^{* * *}$ & $.749 * * *$ & $.727^{* * *}$ \\
\hline \multicolumn{5}{|l|}{ Position (full prof ref) } \\
\hline Associate professor & -.225 & -.123 & $-.264 *$ & $.246 * *$ \\
\hline Lecturer/assistant prof & $-.528 * * *$ & $-.554 * * *$ & -.126 & $.550 * * *$ \\
\hline Academic leader & .499 & .324 & -.412 & $-.498^{*}$ \\
\hline $\begin{array}{l}\text { No national external } \\
\text { research funding }\end{array}$ & $-.800 * * *$ & $-1.415^{* * *}$ & $-.490 * * *$ & $-.375^{* * *}$ \\
\hline External work experience & $.280 * *$ & $.197^{*}$ & .161 & $.220 * *$ \\
\hline Basic research orientation & .048 & .028 & $.102^{*}$ & -.050 \\
\hline $\begin{array}{l}\text { Applied research } \\
\text { orientation }\end{array}$ & $.314^{* * *}$ & $.568 * * *$ & $.355^{* * *}$ & $.389 * * *$ \\
\hline $\begin{array}{l}\text { Total publication points } \\
2011-13\end{array}$ & .045 & .022 & -.036 & .000 \\
\hline $\begin{array}{l}\text { Share of publications in } \\
\text { leading journals }\end{array}$ & -.078 & .296 & .106 & -.323 \\
\hline Constant & $.995 * *$ & $-3.242^{* * *}$ & $-3.044^{* * *}$ & $-.807 * *$ \\
\hline Nagelkerke $\mathrm{R}^{2}$ & .13 & .33 & .17 & .15 \\
\hline $\mathrm{N}$ & 3742 & 3742 & 3742 & 3742 \\
\hline
\end{tabular}

$*=<.05 .{ }^{* *}=<.01 .{ }^{* * *}=<.001$ 
Table 6. Regressions on external engagement, different types of work experience.

\begin{tabular}{|c|c|c|c|c|}
\hline Variable & $\begin{array}{l}\text { Dissemi- } \\
\text { nation }\end{array}$ & $\begin{array}{l}\text { Research } \\
\text { collab. }\end{array}$ & $\begin{array}{l}\text { Commerciali } \\
\text { sation }\end{array}$ & Training \\
\hline Gender (male $=1$, fem $=2$ ) & .003 & -.096 & $-.762 * * *$ & .153 \\
\hline \multicolumn{5}{|l|}{$\begin{array}{l}\text { Field of science } \\
\text { (humanities=ref) }\end{array}$} \\
\hline Social science & .222 & $.771^{* * *}$ & .079 & $.333^{* *}$ \\
\hline $\begin{array}{l}\text { Mathematics/natural } \\
\text { science }\end{array}$ & $-.947 * * *$ & $1.045^{* * *}$ & $.658^{* *}$ & -.043 \\
\hline Engineering/agriculture & $-.775 * * *$ & $1.448 * * *$ & $1.242^{* * *}$ & $-.400 * *$ \\
\hline Medicine/health & -.227 & $1.042 * * *$ & $.590 * *$ & $.622 * * *$ \\
\hline \multicolumn{5}{|l|}{ Position (full prof ref) } \\
\hline Associate professor & $-.235 *$ & -.117 & $-.262 *$ & $.215^{*}$ \\
\hline Lecturer/assistant prof & $-.565 * * *$ & $-.506 * * *$ & -.104 & $.460 * * *$ \\
\hline Academic leader & .543 & .343 & -.462 & $-.461^{*}$ \\
\hline $\begin{array}{l}\text { No national external } \\
\text { research funding }\end{array}$ & $-.815 * * *$ & $-1.393 * * *$ & $-.494 * * *$ & $-.404 * * *$ \\
\hline \multicolumn{5}{|l|}{$\begin{array}{l}\text { External work experience } \\
\text { from: }\end{array}$} \\
\hline Public sector & $.565 * *$ & .119 & $-.713 * * *$ & $.226^{*}$ \\
\hline Research institutes & .051 & $.521 * * *$ & .100 & -.222 \\
\hline Health sector & .255 & -.026 & $.469 * *$ & $.707^{* * *}$ \\
\hline School system & $.312^{*}$ & .000 & -.076 & $.483 * * *$ \\
\hline Industry & .039 & $.298^{* *}$ & $.595 * * *$ & $.218^{*}$ \\
\hline Basic research orientation & .043 & .024 & $.109 *$ & -.053 \\
\hline $\begin{array}{l}\text { Applied research } \\
\text { orientation }\end{array}$ & $.314 * * *$ & $.556 * * *$ & $.351^{* * *}$ & $.388 * * *$ \\
\hline $\begin{array}{l}\text { Total publication points } \\
2011-13\end{array}$ & .045 & .022 & .030 & .003 \\
\hline $\begin{array}{l}\text { Share of publications in } \\
\text { leading journals }\end{array}$ & -.067 & .303 & .021 & -.319 \\
\hline Constant & $1.127^{* *}$ & $-2.995 * * *$ & $-3.723 * * *$ & $-.803 * * *$ \\
\hline Nagelkerke $\mathrm{R}^{2}$ & .14 & .33 & .19 & .17 \\
\hline $\mathrm{N}$ & 3748 & 3748 & 3748 & 3748 \\
\hline
\end{tabular}

$*=<.05 . * *=<.01 . * * *=<.001$ 
Table 7. Regressions on research performance, work experience in general and from specific sectors.

\begin{tabular}{|c|c|c|c|c|c|}
\hline Variable & $\begin{array}{l}\text { Highly } \\
\text { productive } \\
\text { researcher }\end{array}$ & $\begin{array}{l}\text { High quality } \\
\text { researcher }\end{array}$ & & $\begin{array}{l}\text { High } \\
\text { research } \\
\text { productivity }\end{array}$ & $\begin{array}{l}\text { High } \\
\text { research } \\
\text { quality }\end{array}$ \\
\hline Gender (male=1. fem=2) & -.034 & .030 & & -.047 & .024 \\
\hline \multicolumn{6}{|l|}{$\begin{array}{l}\text { Field of science } \\
\text { (humanities=ref) }\end{array}$} \\
\hline Social science & -.229 & -.154 & & -.232 & -.217 \\
\hline $\begin{array}{l}\text { Mathematics/natural } \\
\text { science }\end{array}$ & $-.564 * * *$ & .298 & & $-.567 * * *$ & .240 \\
\hline Engineering/agriculture & $-.386 * *$ & .072 & & $-.367 *$ & .016 \\
\hline Medicine/health & $-.986 * * *$ & -.303 & & $-.989 * * *$ & -.474 \\
\hline \multicolumn{6}{|l|}{ Position (full prof ref) } \\
\hline Associate professor & $-1.005^{* * *}$ & $-.892 * * *$ & & $-1.004 * * *$ & $-.856 * * *$ \\
\hline Lecturer/assistant prof & $-3.532 * * *$ & $-3.343 * * *$ & & $-3.541 * * *$ & $-3.277^{* * *}$ \\
\hline Academic leader & $-1.121 * * *$ & -.558 & & $-1.136 * * *$ & -.583 \\
\hline $\begin{array}{l}\text { No national external } \\
\text { research funding }\end{array}$ & $-.479 * * *$ & $-.538 * * *$ & & $-.475 * * *$ & $-.509 * * *$ \\
\hline \multirow[t]{6}{*}{ External work experience } & -.149 & -.030 & & & \\
\hline & & & Public sector & -.145 & -.085 \\
\hline & & & Res institute & -.005 & .283 \\
\hline & & & Health & -.129 & .251 \\
\hline & & & Schools & -.011 & -.328 \\
\hline & & & Industry & $-.263 *$ & -.307 \\
\hline Basic research orientation & $.420 * * *$ & $.501 * * *$ & & $.419 * * *$ & $.490 * * *$ \\
\hline $\begin{array}{l}\text { Applied research } \\
\text { orientation }\end{array}$ & $-.090^{*}$ & $-.158 * *$ & & $-.087^{*}$ & $-.151^{* *}$ \\
\hline Dissemination active & .187 & -.034 & & .175 & -.045 \\
\hline $\begin{array}{l}\text { Research collaboration } \\
\text { active }\end{array}$ & $.239 *$ & $.316^{*}$ & & $.244^{*}$ & $.309 *$ \\
\hline Commercialisation active & $-.312^{*}$ & -.196 & & $-.305^{*}$ & -.190 \\
\hline Active in training & -.081 & $-.271^{*}$ & & -.074 & -.257 \\
\hline Constant & $-1.778 * * *$ & $-3.427^{* * *}$ & & $-1.780 * * *$ & $-3.229 * * *$ \\
\hline Nagelkerke $\mathrm{R}^{2}$ & .32 & .24 & & .32 & .24 \\
\hline $\mathrm{N}$ & 37406 & 37406 & & 3746 & 3746 \\
\hline
\end{tabular}

